\title{
Kommentar
}

\section{Gamle som faller}

I sagaen om Egil Skallagrimsson (910-990) finner vi vår eldste kjente skildring av fall hos gamle (1). På tross av et langt liv i strid ble Egil gammel. Mot slutten av livet sviktet både syn og hørsel, og han var ikke lenger stø på foten. En dag han gikk ute på gården, falt han pladask. Noen kvinnfolk som så dette, tok da til å gapskratte. En av dem sa: «Nå er det ute med deg, Egil, siden du ikke kan gå aleine.» Foruten å illustrere datidens grovkornede humor forteller historien at man også for mer enn tusen år siden hadde erfart at den som faller av seg selv, har reduserte livsutsikter.

$\AA$ «falle av seg selv» er en type hendelse som rammer de fleste bare man blir gammel nok. Årsaken kan være alt fra banal til potensielt fatal. Komplikasjoner som lårhalsbrudd er spesielt fryktet.

For hjemmeboende eldre er fastlegen som oftest nærmeste legekontakt når det gjelder fall og tendensen til å falle. Fastlegen skal både avklare følger av fallet og sannsyn$\operatorname{lig}(\mathrm{e})$ årsak(er). Gamle mennesker har redusert psykomotorisk hurtighet og er dårligere til å «hevle» seg (ta seg inn igjen ved kroppslig ubalanse) (2). De har også dårligere autoregulering av puls og blodtrykk og er mer sårbare for medikameneffekter.

Synkope er akutt anfall med tap av bevissthet og muskeltonus på grunn av redusert cerebral blodstrøm. Varigheten er typisk 20-30 sekunder. Fall uten bevissthetstap skal derfor ikke utredes som synkope. I kli- nisk praksis kan imidlertid grensene mellom synkope, nærsynkope og fall være uklare. Desto viktigere er det at utredningen er systematisk og målrettet (3). Som så ofte ellers i medisinen er oppbygging av en god sykehistorie viktigst for diagnosen. Fallanamnesen skal avklare om pasienten snublet eller om fallet skyldtes bevissthetstap, som ved synkope. Hva husker pasienten, og hva har komparenter observert?

Den kliniske undersøkelsen på legekontoret bør også inkludere vurdering av gangfunksjon og stødighet, orienterende nevrologisk undersøkelse og måling av sittende og stående blodtrykk, og den bør suppleres med EKG-undersøkelse samt blodprøver bestemt ut fra klinisk mistanke (3). Kronologisk alder er i seg selv ingen kontraindikasjon for henvisning til spesialistundersøkelse. Jo eldre den som har synkopert er, desto større er sannsynligheten for bakenforliggende sykdom. Så mye som en tredel av alle synkoper hos gamle har kardial årsak. Spesielt er det viktig å oppdage arytmier og strukturelle forhold, som aortastenose $(4,5)$. Mens vasovagale synkoper vanligvis ikke er henvisningsgrunn, indiserer mistanke om arytmi eller strukturell hjertesykdom rask henvisning til kardiolog.

Selv om kasuistikken til Haakonsen og medarbeidere mangler en endelig «fasit», er den en nyttig påminnelse om viktigheten av rask diagnostisk utredning og behandling ved kardial synkope. Den minner oss også om hvor viktig en fyldig og relevant henvisning er for at mottakeren skal kunne prioritere riktig. For pasienten kan resultatet for eksempel bli medisinomlegging, innsetting av pacemaker eller ny aortaklaff. Mange eldre har fått lagt flere gode år til sitt livsløp takket være slike behandlinger. Å medvirke til dette er takknemlig legearbeid.

\section{Jørund Straand}

jorund.straand@medisin.uio.no

Jørund Straand (f. 1951) er professor i allmennmedisin, avdelingsleder ved Avdeling for allmennmedisin og forskningsleder ved Allmennmedisinsk forskningsenhet, Institutt for helse og samfunn, Universitetet i Oslo.

\section{Litteratur}

1. Egilssoga. Oversatt av Leiv Heggstad. Oslo: Det Norske Samlaget, 2008.

2. Aasen I. Norsk ordbog med dansk forklaring Christiania: P.T. Mallings, 1873.

3. Wyller TB. Geriatri. En medisinsk lærebok. Kap. 7 , 19 og 41. Oslo: Gyldendal, 2011.

4. Parry SW, Tan MP. An approach to the evaluation and management of syncope in adults. BMJ 2010; 340: $c 880$.

5. Del Rosso A, Alboni P, Brignole M et al. Relation of clinical presentation of syncope to the age of patients. Am J Cardiol 2005: 96: 1431-5.

Mottatt 3.9.2013 og godkjent11.10. 2013. Redaktør Merete Kile Holtermann. 